\title{
Effects of acclimation temperature on critical thermal limits and swimming performance of the state-endangered bigeye chub Hybopsis amblops
}

\author{
Qihong Dai* , Cory D. Suski \\ Department of Natural Resources and Environmental Sciences, University of Illinois, Urbana-Champaign, Urbana, IL 61801, USA
}

\begin{abstract}
Thermal stress can directly affect the survival of fishes and indirectly impact fish populations through several processes, including impaired swimming performance. Bigeye chub Hybopsis amblops is a state-endangered species in Illinois and is disappearing in the northern portion of its native range in North America. Limited temperature tolerance information exists on this species. The aim of this study was to define the impacts of 2 acclimation temperatures on the performance and behavior of bigeye chub. To accomplish this, we conducted 2 assays: critical thermal maximum $\left(\mathrm{CT}_{\max }\right)$ testing for upper thermal tolerance limits, and swimming performance testing for critical swimming speed $\left(U_{\text {crit }}\right)$ and burst swimming ability. With a $5^{\circ} \mathrm{C}$ acclimation temperature increase from 21 to $26^{\circ} \mathrm{C}_{\text {, the }} \mathrm{CT}_{\max }$ of bigeye chub increased from $32.8 \pm 0.4^{\circ} \mathrm{C}$ to $36.4 \pm$ $0.9^{\circ} \mathrm{C}$. $U_{\text {crit }}$ was not different across acclimation temperatures, and fish from both acclimation groups could swim up to over 10 body lengths (BL) $\mathrm{s}^{-1}$. Burst swimming duration also did not differ statistically across groups, but bigeye chub from the $26^{\circ} \mathrm{C}$ group swam $27 \%$ longer in duration relative to fish from the $21^{\circ} \mathrm{C}$ group. Results from this study can help guide the protection and restoration of bigeye chub populations from thermal stressors.
\end{abstract}

KEY WORDS: $\mathrm{CT}_{\max } \cdot \mathrm{AT}_{\max } \cdot$ Thermal tolerance $\cdot U_{\text {crit }} \cdot$ Burst swimming $\cdot$ Global warming $\cdot$ Range distribution $\cdot$ Endangered

\section{INTRODUCTION}

For ectothermic organisms including fish, temperature is one of the most critical abiotic factors, and is recognized as an important ecological resource (Magnuson et al. 1979). Although acclimation to higher temperature can increase the upper thermal tolerance of fish, the scope of this enhanced tolerance decreases at higher tolerable acclimation temperatures (Beitinger et al. 2000). As a result, with exposure to sustained elevated temperatures or more intermittent heat waves, fish can suffer negative consequences including increased energy use, impaired swimming performance, reductions in fitness, altered range limits, or even death (Huey 1991, Beitinger et al. 2000, Xia et al. 2017, Morgan et al. 2018). To pro-

${ }^{*}$ Corresponding author: qihongd2@illinois.edu tect and restore populations of various fish species, it is therefore important to be able to quantify thermal tolerance and predict the possible impacts of thermal challenges.

Bigeye chub Hybopsis amblops is a member of the Leuciscinae subfamily (Page \& Burr 2011), and these fish are commonly known as small minnows (Avise \& Ayala 1976). The species once had a widespread distribution in North America, from the drainages of Lakes Ontario and Erie in the north to the Tennessee River drainage in the south (Page \& Burr 2011). It is typically found in clear, gravel-bottomed streams with permanent flow and little silt, preferring to reside at the base of riffles or in quiet pools (Pfleiger 1997). The presence of bigeye chub has been viewed as an indicator of excellent water quality (Boschung

() The authors 2019. Open Access under Creative Commons by Attribution Licence. Use, distribution and reproduction are unrestricted. Authors and original publication must be credited. 
\& Mayden 2004). Bigeye chub distributions have been greatly reduced, particularly in the northern portion of their native range (Tiemann et al. 2004). At present, the species is believed to have been extirpated from Michigan and Virginia and is listed as an endangered species in Illinois (Warren \& Burr 1988, Angermeier 1995, Berendzen et al. 2008, Illinois Endangered Species Protection Board 2015). The extirpation of bigeye chub in parts of its range has been attributed to bank siltation and release of fertilizers and pesticides from poor agricultural practices (Page \& Retzer 2002); thermal stressors could also be contributing to its decline. For example, for stream fish, loss of riparian habitats is known to exacerbate the impacts of thermal challenges (Naiman \& Décamps 1997) under more frequent heat waves and elevated temperatures (IPCC 2018). At present, however, there is one study on thermal tolerance of bigeye chub, using only one fish acclimated to a single temperature (Lutterschmidt \& Hutchison 1997). Additional data on the thermal tolerance of bigeye chub are therefore essential to better understand and protect this rare species in the face of thermal stressors.

To quantify the direct and indirect impacts of thermal stressors on fishes, critical thermal maximum $\left(\mathrm{CT}_{\max }\right)$ (Lutterschmidt \& Hutchison 1997, Beitinger \& Lutterschmidt 2011) and swimming performance (Xia et al. 2017) testing, respectively, are commonly used. $\mathrm{CT}_{\max }$ is a laboratory-based procedure commonly used to define upper thermal tolerance limits of aquatic ectothermic animals and determine species' distributions (Sears et al. 2011). Compared to other dynamic or static assays, $\mathrm{CT}_{\max }$ has emerged as the mostly widely used procedure, with the number of thermal tolerance studies using $\mathrm{CT}_{\max }$ increasing 500\% from 1990-2000 to 2010-2017 (Morgan et al. 2018). The procedure to define tolerance limits for fish using $\mathrm{CT}_{\max }$ consists of increasing water temperature at a constant rate until a sublethal endpoint, such as the loss of equilibrium or the onset of spasms, is reached (Lutterschmidt \& Hutchison 1997). Compared to other methods, such as incipient upper lethal temperature, $\mathrm{CT}_{\max }$ has 2 main advantages: (1) it is a nonlethal method that requires relatively small sample sizes, which makes it ideally suited to the study of threatened species; and (2) it is very effective when evaluating the impacts of biotic (e.g. competition) and abiotic factors (e.g. pollution) on thermal tolerance (Becker \& Genoway 1979, Beitinger \& Lutterschmidt 2011). To date, different abiotic factors have been incorporated in thermal tolerance tests, and among these acclimation temperature has shown a positive relationship with $\mathrm{CT}_{\max }$ (Bennett \& Beitinger 1997,
Beitinger \& Lutterschmidt 2011), suggesting that the physiological plasticity of fish could help reduce the impacts of thermal challenges (Underwood et al. 2012).

In addition to directly quantifying thermal limits using $\mathrm{CT}_{\max }$ tests, quantifying temperature-regulated swimming is an efficient way to define how thermal acclimation can impact performance and survival of fish in a laboratory setting (Plaut 2001) because swimming ability is critical for activities such as prey capture, predator avoidance, and reproduction in natural populations (Killen et al. 2010). Fish typically have a thermal optimum for swimming, and temperatures that exceed this optimum result in decreased swimming performance that can have negative consequences for survival and fitness (Lee et al. 2003). Thus, better understanding of the thermal tolerance of bigeye chub, as well as an improved ability to predict the response of bigeye chub to thermal challenges, can be achieved using $\mathrm{CT}_{\max }$ and swimming performance testing across a range of acclimation temperatures.

To better protect and restore bigeye chub populations, the objectives of this study were to (1) quantify the upper critical thermal limits, (2) define the influence of acclimation temperatures on swimming performance, and (3) compare the thermal tolerance and swimming performance of bigeye chub to other Leuciscinae species. These 3 objectives will combine to improve our ability to quantify how thermal challenges can influence bigeye chub populations.

\section{MATERIALS AND METHODS}

\subsection{Fish sampling and release}

On 25 October 2018, an initial group of bigeye chub ( $\mathrm{n}=12$ ) were collected from the Middle Fork Vermilion River $\left(40^{\circ} 12^{\prime} \mathrm{N}, 87^{\circ} 44^{\prime} \mathrm{W}\right)$ at Kennekuk Cove County Park near Danville, IL, USA. Fish were sampled using a seine net, placed in coolers with aerators, and brought back to the University of Illinois Aquatic Research Facility in Urbana-Champaign. These 12 individuals were held in a single aerated aquarium to confirm their transition to consuming dry fish flakes (Freshwater Flakes; Omega One) in the laboratory. Following successful transition to flaked food within $1 \mathrm{~d}$, an additional 28 bigeye chub were then sampled at the same site on 31 October 2018 using the same sampling techniques described above. Species identification of individual fish was confirmed by biologists working for the Illinois Department of Natural Resources. 
After all experiments described below, all live fish were released back to the original sampling site after cooling acclimation temperature to match environmental temperatures.

\subsection{Fish holding and acclimation}

Thermal acclimation occurred in 2 identical 1101 glass aquaria (20 bigeye chub aquarium ${ }^{-1}$ ). Each aquarium was filled with dechlorinated, conditioned tap water (AquaSafe Plus; Tetra), covered with gravel on the bottom, and outfitted with a power filter to maintain water quality (Aqua Clear Power Filter; Marineland). Lights for the aquaria were automatically turned on at 06:00 $\mathrm{h}$ and off at 18:00 h every day by timers, and fish were fed to satiation daily with dry fish flakes. Dissolved oxygen was measured daily (Pro Plus Multiparameter Instrument; YSI) and remained above $90 \%$ saturation. Every week, $10 \%$ of the water in each tank was replaced with fresh dechlorinated tap water, and excess food and feces in the bottom of the tanks were regularly removed using a siphon. Water temperature was set to $11^{\circ} \mathrm{C}$ (i.e. field temperature) for both aquaria at the beginning of the experiment (TK-500; TECO); 2 d later, water temperature was increased at a rate of $1^{\circ} \mathrm{C} \mathrm{d}^{-1}$ (Xia et al. 2017) until 21 and $26^{\circ} \mathrm{C}$ were reached, respectively representing mean water temperature in May and August 2016 at our sampling site, based on records from the Illinois Environmental Protection Agency monitoring station (https://www2.illinois.gov/ epa/topics/water-quality/monitoring/Pages/river-andstream.aspx). Once target acclimation temperatures were reached, 10 bigeye chub from each temperature group were randomly selected and gently moved to a second, identical aquarium with the same water quality parameters. Thus, altogether, there were 4 acclimation aquaria used ( 2 aquaria at $21^{\circ} \mathrm{C}$ and 2 at $26^{\circ} \mathrm{C}$ ), each holding 10 individuals. Fish were then held for $21 \mathrm{~d}$ at target acclimation temperatures to ensure thermal acclimation, and harmful
ammonia-N was quickly reduced to $0 \mathrm{ppm}$ by nitrifying bacteria (Currie et al. 1998, Carveth et al. 2006, Xia et al. 2017) (Table 1). During holding, there was no sign of any fungus on the fish, and all animals appeared to be robust, healthy, and vigorous. Neither total length (TL), total weight (TW), nor condition score (Fulton's condition factor, $K$, calculated as: TW / $\mathrm{TL}^{3} \times 10^{5}$ ) (Neumann et al. 2012) differed across temperature groups ( $t$-tests, $t_{38}<1.7, \mathrm{p}>0.05$ ) (Table 1).

\subsection{Critical thermal limit testing}

Critical thermal limit tests occurred after the $21 \mathrm{~d}$ acclimation period, and all fish were fasted for $24 \mathrm{~h}$ prior to testing to reduce the impact of feeding on any behavioral response. Critical thermal limit testing was carried out in a 751 testing tank containing 551 of dechlorinated tap water. The tank contained a $1000 \mathrm{~W}$ electric immersion heater for temperature increase (SmartOne EasyPlug Axial Bottom Heater; Integrated Aqua Systems), 2 small aquarium pumps to mix water in the tank (Universal 600; Eheim), and an air stone attached to a small compressor (Tetra Whisper; Tetra) for aeration. A total of 6 individually numbered plastic compartments $(20 \times 10 \times 10 \mathrm{~cm})$ were attached to the sides of the tank and used to hold fish during testing. These compartments were perforated with holes to allow the circulation of water, but kept fish confined to minimize the likelihood of fish disturbing each other, and to make it easier to monitor individuals during the trial (Amundsen $\&$ Forsgren 2001). Either 4 or 6 fish were introduced into the compartments during each trial, and fish were given $1 \mathrm{~h}$ of acclimation time with nearly $100 \%$ saturation of dissolved oxygen $\left(>7.5 \mathrm{mg} \mathrm{l}^{-1}\right)$ and water temperature identical to acclimation temperature (i.e. 21 or $26^{\circ} \mathrm{C}$ ).

After $1 \mathrm{~h}$ acclimation, the air stone was removed from the tank, and water temperature was increased at a rate of $0.3^{\circ} \mathrm{C} \mathrm{min}^{-1}$ (Beitinger et al. 2000, Beitinger

Table 1. Mean $( \pm \mathrm{SD})$ water quality parameters and fish sizes for bigeye chub held at either 21 or $26^{\circ} \mathrm{C}$ during a $3 \mathrm{wk}$ acclimation period $\left(n=20\right.$ fish treatment $\left.{ }^{-1}\right)$. Dissolved oxygen, total length $(\mathrm{TL})$, total weight $(\mathrm{TW})$ and condition factor $(K)$ did not differ across temperature treatments ( $t$-tests, $t_{38}<1.7, \mathrm{p}>0.05$ ). $K$, a metric to compare fish weight relative to its length, was calculated as: TW $/ \mathrm{TL}^{3} \times 10^{5}$

\begin{tabular}{|lccccc|}
\hline $\begin{array}{l}\text { Target acclimation } \\
\text { temperature }\left({ }^{\circ} \mathrm{C}\right)\end{array}$ & $\begin{array}{c}\text { Water temperature } \\
\text { during holding }\left({ }^{\circ} \mathrm{C}\right)\end{array}$ & $\begin{array}{c}\text { Dissolved oxygen } \\
(\% \text { saturation })\end{array}$ & $\begin{array}{c}\text { Total length } \\
(\mathrm{TL})(\mathrm{mm})\end{array}$ & $\begin{array}{c}\text { Total weight } \\
(\mathrm{TW})(\mathrm{g})\end{array}$ & $\begin{array}{c}\text { Condition factor } \\
(K)\end{array}$ \\
\hline 21 & $21.1 \pm 0.2$ & $99.0 \pm 1.7$ & $68.5 \pm 7.2$ & $2.9 \pm 0.9$ & $0.87 \pm 0.06$ \\
26 & $26.0 \pm 0.2$ & $98.5 \pm 1.6$ & $68.2 \pm 5.7$ & $2.7 \pm 0.7$ & $0.83 \pm 0.10$ \\
\hline
\end{tabular}


\& Lutterschmidt 2011) (Fig. A1 in the Appendix). Every fish was closely observed for 2 different behavioral responses as temperature increased. First, the temperature at which fish displayed erratic behaviors, defined by burst swimming or attempts to jump out of their compartments, was recorded as the upper incipient avoidance temperature $\left(\mathrm{AT}_{\max }\right)$ (Xia et al. 2017). Second, the temperature at which fish started to lose body equilibrium, defined by disorganization of locomotion and failure to maintain dorso-ventral orientation, was recorded as $\mathrm{CT}_{\max }$ (Beitinger et al. 2000, Xia et al. 2017, Morgan et al. 2018). Once a fish lost equilibrium, it was quickly removed from its compartment, measured for TL and TW, and placed in a nearby holding tank with water at the acclimation temperature for recovery. During the trial, temperature was recorded every 1 min with the same YSI handheld meter described above. Dissolved oxygen was monitored regularly and did not fall below $98 \%$ saturation ( $>7.5 \mathrm{mg} \mathrm{l}^{-1}$ ) despite the lack of aeration during observations. Altogether, a total of 8 trials were run, with sample size of $n=20$ bigeye chub for each acclimation temperature. Trials for each temperature treatment were run on a single day to minimize the impacts of holding duration on any response to thermal challenges. After the conclusion of all trials, fish were returned to their acclimation aquaria and continued to be fed daily for $72 \mathrm{~h}$ and monitored for potential delayed mortality.

\subsection{Swimming performance testing}

After $1 \mathrm{wk}$ of critical thermal tolerance testing, tests of critical swimming speed ( $\left.U_{\text {crit }}\right)$ and burst swimming duration were performed in a $51(30 \times 7.5 \times 7.5 \mathrm{~cm})$ flow-controlled swim tunnel respirometer (Loligo; www.loligosystems.com). The swim tunnel was calibrated using a flow meter (HFA; Höntzsch) to convert motor speed to water velocity $\left(\mathrm{cm} \mathrm{s}^{-1}\right)$. Bigeye chub were fasted for $24 \mathrm{~h}$ prior to swimming tests to reduce the impact of feeding on any behavioral response. For $U_{\text {crit }}$ tests, at each acclimation temperature, a single fish was randomly selected at one time and gently transferred to the swim tunnel, flowing at $5 \mathrm{~cm} \mathrm{~s}^{-1}$ (approximately 0.7 body lengths [BL] s${ }^{-1}$ ) for $30 \mathrm{~min}$ acclimation (Underwood et al. 2014, Kern et al. 2018). Water temperature in the tunnel was held close to acclimation temperature $\left( \pm 0.5^{\circ} \mathrm{C}\right)$ using a submersible $100 \mathrm{~W}$ aquarium heater (Top Fin). Following the 30 min acclimation, water velocity was increased by $5 \mathrm{~cm} \mathrm{~s}^{-1}$ every $5 \mathrm{~min}$ (Kern et al. 2018) until the fish became exhausted, determined when the fish failed to move off the rear screen of the chamber for $>5 \mathrm{~s}$. Once exhaustion was reached, the fish was gently removed from the swim tunnel, measured for TL and TW, and returned to its holding aquarium. Individuals were only tested in one swimming challenge. Trials for each temperature treatment were run on a single day to minimize the impacts of holding duration on any response to thermal challenges.

$U_{\text {crit }}$ was calculated as:

$$
U_{\text {crit }}=U+(t / T) \times \Delta U
$$

where $U\left(\mathrm{~cm} \mathrm{~s}^{-1}\right)$ is the highest sustained water velocity fish achieved for full $5 \mathrm{~min}, \Delta U$ is the velocity increment (i.e. $5 \mathrm{~cm} \mathrm{~s}^{-1}$ ), $t$ (min) is the time fish swam during the final increment, and $T$ is the time increment (i.e. $5 \mathrm{~min}$ ) (Brett 1964). A correction for blocking was not performed because the maximal crosssectional area of bigeye chub was $<10 \%$ of the cross section in the swim tunnel (Bell \& Terhune 1970), with measurements verified using calipers for each fish. Sample sizes for these tests were 5 fish from each acclimation temperature.

For burst swimming testing, at each acclimation temperature, a single bigeye chub was randomly selected at one time among remaining individuals in aquaria and acclimated to the swim tunnel for $5 \mathrm{~min}$ at $0.5 \mathrm{BL}$ $\mathrm{s}^{-1}$ (approximately $0.35 \mathrm{~cm} \mathrm{~s}^{-1}$ ) (Underwood et al. 2014, Kern et al. 2018). Following this acclimation, water velocity was increased to $12 \mathrm{BL} \mathrm{s}^{-1}$ in $5 \mathrm{~s}$ and swim duration then was recorded by a timer (Hasler et al. 2009). This increase in water velocity was chosen because the converted mean $U_{\text {crit }}$ from the previous tests was larger than $10 \mathrm{BL} \mathrm{s}^{-1}$ but smaller than $12 \mathrm{BL} \mathrm{s}^{-1}$, and a high velocity was necessary to ensure that fish were not swimming aerobically. Following this rapid increase in water velocity, fish swam until they could not move off the rear screen of the chamber for $>3 \mathrm{~s}$. Once swimming ceased, the fish was gently removed from the swim tunnel and measured for TL and TW. Sample sizes were 6 fish from each acclimation temperature. Trials for each temperature treatment were run on a single day to minimize the impacts of holding duration on any response to thermal challenges.

\subsection{Statistical analyses}

For thermal tolerance testing, comparisons of both $\mathrm{CT}_{\max }$ and $\mathrm{AT}_{\max }$ for each acclimation temperature were conducted using a single 2-way ANOVA. The main effects were acclimation temperature (21 or $\left.26^{\circ} \mathrm{C}\right)$, response $\left(\mathrm{AT}_{\max }\right.$ and $\left.\mathrm{CT}_{\max }\right)$, and their interaction. If a significant difference was found for any term 
in the model, post hoc analyses to determine differences across factors were performed using a Tukey's HSD test. Following the completion of this 2-way ANOVA, an additional analysis was conducted using a fully parameterized model to quantify the impacts of $K$, trial number, compartment number, and holding aquarium on both $\mathrm{AT}_{\max }$ and $\mathrm{CT}_{\max }$. The model that contained only acclimation temperature, response, and their interaction was compared to the fully parameterized model using a 1-way ANOVA (Crawley 2013).

For swimming performance testing, both $U_{\text {crit }}$ and burst swimming duration were compared across acclimation temperatures using separate 1-way ANOVAs. An additional analysis was conducted to quantify the impacts of $K$ and holding aquarium for both $U_{\text {crit }}$ and burst swimming duration, using a 1-way ANOVA comparing the model containing only temperature with the full parameterized model (Crawley 2013).

All statistical analyses were conducted in R v.3.5.1 (R Core Team 2019) with $\alpha=0.05$, and all data are reported \pm SD where appropriate. Fit of all models to the data, as well as assumptions of normality and equal variances, were verified with inspection of residuals and quantile-quantile plots (Crawley 2013).

\section{RESULTS}

\subsection{Critical thermal limits}

Bigeye chub acclimated to $26^{\circ} \mathrm{C}$ began to show avoidance behaviors (i.e. $\mathrm{AT}_{\max }$ ) and lost equilibrium (i.e. $\mathrm{CT}_{\max }$ ) at 3.4 and $3.6^{\circ} \mathrm{C}$ higher, respectively, than fish acclimated to $21^{\circ} \mathrm{C}$ (Tukey's HSD, $\mathrm{p}<0.05$ ) (Table 2). The temperature causing equilibrium loss

Table 2. Temperature at which bigeye chub showed either avoidance behaviors (upper incipient avoidance temperature $\left[\mathrm{AT}_{\max }\right]$ ) or lost equilibrium (critical thermal maximum $\left.\left[\mathrm{CT}_{\text {max }}\right]\right)$ acclimated to either 21 or $26^{\circ} \mathrm{C}$. Results from statistical tests are shown in Table A1. $\left({ }^{*}\right)$ indicates a significant difference between $\mathrm{CT}_{\max }$ and $\mathrm{AT}_{\max }$ superscript letters denote differences across acclimation temperatures. Sample sizes: $\mathrm{n}=20$ per acclimation temperature

\begin{tabular}{|lcccc|}
\hline Response & $\begin{array}{c}\text { Acclimation } \\
\text { temperature }\left({ }^{\circ} \mathrm{C}\right)\end{array}$ & Mean & SD & Median \\
\hline $\mathrm{AT}_{\max }{ }^{*}$ & $21^{\mathrm{a}}$ & 29.9 & 1.3 & 29.9 \\
$\mathrm{CT}_{\max }$ & $26^{\mathrm{b}}$ & 33.3 & 1.4 & 33.6 \\
& $21^{\mathrm{a}}$ & 32.8 & 0.4 & 32.8 \\
& $26^{\mathrm{b}}$ & 36.4 & 0.9 & 36.6 \\
\hline
\end{tabular}

was significantly higher than the temperature causing avoidance behaviors (Table 2 and Table A1 in the Appendix).

The behavioral responses of bigeye chub during the thermal testing were not influenced by compartment number $\left(F_{1,72}=0.108, \mathrm{p}=0.744\right)$ or holding aquarium $\left(F_{1,72}=1.117, \mathrm{p}=0.294\right)$. However, behavioral responses were influenced by trial number $\left(F_{1,72}=7.598, \mathrm{p}=0.007\right)$ and $K\left(\mathrm{~F}_{1,72}=4.519, \mathrm{p}=\right.$ 0.037). Inspection of $\mathrm{CT}_{\max }$ and $\mathrm{AT}_{\max }$ data across trials showed that changes in responses across trials were small $\left(\leq 1.8^{\circ} \mathrm{C}\right.$ on average across replicates), and no consistent or predictable changes in behavioral responses occurred over time (Fig. A2).

During the monitoring period that followed thermal testing, 1 bigeye chub from the $26^{\circ} \mathrm{C}$ group died. The $K$ for this individual was 0.61 , which is considerably below average in the study (approximately $K=$ 0.85 ; Table 1). After excluding this individual from analyses, $K$ no longer significantly influenced either $\mathrm{CT}_{\text {max }}$ or $\mathrm{AT}_{\text {max }}\left(F_{1,70}=2.620, \mathrm{p}=0.110\right)$, indicating that the significant impact of $K$ on behavioral responses was driven by this single fish. Despite this effect, the individual was retained in the analyses of $\mathrm{CT}_{\max }$ and $\mathrm{AT}_{\max }$ because excluding this data point did not impact $\mathrm{CT}_{\max }$ or $\mathrm{AT}_{\max }$, verified by unpaired, 2 sample $t$-tests $\left(\mathrm{CT}_{\max }: t_{77}=-0.11, \mathrm{p}=0.91 ; \mathrm{AT}_{\max }\right.$ : $\left.t_{77}=0.03, \mathrm{p}=0.98\right)$. In addition, this individual did not demonstrate any stress-like or abnormal behavior prior to the monitoring period.

\subsection{Swimming performance}

Neither $U_{\text {crit }}\left(F_{1,8}=0.537, \mathrm{p}=0.485\right)$ nor burst swimming duration $\left(F_{1,10}=0.815, \mathrm{p}=0.388\right)$ differed statistically between the 21 and $26^{\circ} \mathrm{C}$ groups, even though the mean burst swimming duration of fish from the $26^{\circ} \mathrm{C}$ group was $27 \%$ higher than fish from the $21^{\circ} \mathrm{C}$ group (Table 3). The swimming performance of bigeye chub for $U_{\text {crit }}\left(F_{8,6}=0.104, \mathrm{p}=0.903\right)$ or burst swimming duration $\left(F_{10,8}=0.788, \mathrm{p}=0.487\right)$ was not influenced by $K$ or holding aquarium.

\section{DISCUSSION}

This is the first comprehensive study to define the thermal tolerance of bigeye chub. The $\mathrm{CT}_{\max }$ of bigeye chub acclimated to $21^{\circ} \mathrm{C}$ was $32.8 \pm 0.4^{\circ} \mathrm{C}$; a $5^{\circ} \mathrm{C}$ increase in acclimation temperature increased $\mathrm{CT}_{\max }$ to $36.4 \pm 0.9^{\circ} \mathrm{C}$. Standardized thermal tolerance measurements, such as $\mathrm{CT}_{\max }$, have been commonly 
Table 3. Effects of acclimation temperature on critical swimming speed ( $\left.U_{\text {crit }}\right)$ shown in absolute swimming velocity $(\mathrm{cm}$ $\mathrm{s}^{-1}$ ) or relative swimming speed in body lengths (BL) (BL s ${ }^{-1}$ ), along with burst swimming duration (s) for bigeye chub acclimated to either 21 or $26^{\circ} \mathrm{C}$. Sample sizes: 5 per acclimation temperature for $U_{\text {criti }} 6$ per acclimation temperature for burst swimming duration. $U_{\text {crit }}$ were presented in both absolute and relative velocity to facilitate comparisons with previously published studies. Differences across temperatures within a swimming test were not significantly different; outputs from statistical testing are provided in the results

\begin{tabular}{|lcccc|}
\hline & $\begin{array}{c}\text { Acclimation } \\
\text { temperature }\left({ }^{\circ} \mathrm{C}\right)\end{array}$ & Mean & SD & Median \\
\hline$U_{\text {crit }}\left(\mathrm{cm} \mathrm{s}^{-1}\right)$ & 21 & 71.1 & 3.7 & 70.5 \\
& 26 & 76.6 & 10.8 & 76.0 \\
$U_{\text {crit }}\left(\mathrm{BL} \mathrm{s}^{-1}\right)$ & 21 & 10.8 & 1.5 & 10.7 \\
& 26 & 11.3 & 0.9 & 11.6 \\
Burst swimming & 21 & 9.3 & 4.0 & 9.5 \\
duration (s) & 26 & 11.8 & 5.5 & 10.5 \\
\hline
\end{tabular}

used to quantify the impacts of thermal challenges on aquatic organisms (Terblanche et al. 2011). Despite various rates of temperature changes (i.e. from $1^{\circ} \mathrm{C} \mathrm{h}^{-1}$ to $1^{\circ} \mathrm{C} \mathrm{min}^{-1}$ ) used for $\mathrm{CT}_{\max }$ over the past few decades, $0.3^{\circ} \mathrm{C} \mathrm{min}^{-1}$ has been widely used recently for thermal testing as it ensures the core temperatures of small fish species change consistently and closely with water temperature changes, while also eliminating the possibility of rapid acclimation that can occur at slower temperature increase (Beitinger et al. 2000). In this way, $\mathrm{CT}_{\max }$ provides a consistent, repeatable, and nonlethal approach to define thermal tolerance limits for free-swimming fishes. Lutterschmidt \& Hutchison (1997) reported the $\mathrm{CT}_{\max }$ of a single bigeye chub acclimated to $10^{\circ} \mathrm{C}$ to be $31.7^{\circ} \mathrm{C}$ (Table 4). The lack of replication in that study prevents any general conclusions. Also, they used a relatively fast temperature increase (i.e. $1^{\circ} \mathrm{C} \mathrm{min}{ }^{-1}$ ) during thermal tolerance measurements that could have generated higher $\mathrm{CT}_{\max }$ values compared to the $0.3^{\circ} \mathrm{C} \mathrm{min}^{-1}$ used here, due to the lag of core temperature increase (Beitinger et al. 2000).

Bigeye chub is a member of the subfamily Leuciscinae (i.e. minnows), and comparisons of thermal tolerance data from this study with other Leuciscinae species, which minimize the influence of phylogeny in thermal sensitivity (Hasnain et al. 2013), show that bigeye chub have moderate thermal tolerance (Table 4). For example, sand shiner Notropis strami-

Table 4. Comparisons of the critical thermal maximum $\left(\mathrm{CT}_{\max }\right)( \pm \mathrm{SD}$ when available $)$ of bigeye chub with other small Leuciscinae species (i.e. small minnows) found in the United States. $\Delta T$ : the rate at which water was heated during the thermal trial

\begin{tabular}{|c|c|c|c|c|}
\hline Species & $\begin{array}{c}\text { Acclimation } \\
\text { temperature }\left({ }^{\circ} \mathrm{C}\right)\end{array}$ & $\begin{array}{c}\Delta T \\
\left({ }^{\circ} \mathrm{C} \min ^{-1}\right)\end{array}$ & $\mathrm{CT}_{\max }\left({ }^{\circ} \mathrm{C}\right)$ & Sources \\
\hline Bigeye chub Hybopsis amblops & $\begin{array}{l}21 \\
26 \\
10\end{array}$ & $\begin{array}{c}0.3 \\
0.3 \\
1\end{array}$ & $\begin{array}{l}32.8 \pm 0.4 \\
36.4 \pm 0.9 \\
\quad 31.7\end{array}$ & $\begin{array}{l}\text { This study (2019) } \\
\text { Lutterschmidt \& Hutchison (1997) }\end{array}$ \\
\hline Fathead minnow Pimephales promelas & $\begin{array}{l}23 \\
32\end{array}$ & $\begin{array}{l}0.3 \\
0.3\end{array}$ & $\begin{array}{c}34.4 \\
40.4 \pm 0.3\end{array}$ & $\begin{array}{l}\text { Heath et al. (1994) } \\
\text { Richards \& Beitinger (1995) }\end{array}$ \\
\hline Loach minnow Rhinichthys cobitis & $\begin{array}{l}25 \\
30\end{array}$ & $\begin{array}{l}0.3 \\
0.3\end{array}$ & $\begin{array}{l}35.3 \\
36.1\end{array}$ & Bonar et al. (2005) \\
\hline Spikedace Meda fulgida & $\begin{array}{l}25 \\
30\end{array}$ & $\begin{array}{l}0.3 \\
0.3\end{array}$ & $\begin{array}{l}34.7 \pm 0.9 \\
36.9 \pm 1.1\end{array}$ & Bonar et al. (2005) \\
\hline Red shiner Cyprinella lutrensis & $\begin{array}{l}25 \\
30\end{array}$ & $\begin{array}{l}0.3 \\
0.3\end{array}$ & $\begin{array}{c}37.4 \\
39.6 \pm 0.2\end{array}$ & $\begin{array}{l}\text { King et al. (1985) } \\
\text { Rutledge \& Beitinger (1989) }\end{array}$ \\
\hline Mohave tui chub Gila bicolor mohavensis & $\begin{array}{l}18 \\
24 \\
30\end{array}$ & $\begin{array}{l}0.14 \\
0.14 \\
0.14\end{array}$ & $\begin{array}{l}33.5 \\
34.9 \\
36.2\end{array}$ & McClanahan et al. (1986) \\
\hline Roundtail chub Gila robusta seminuda & $\begin{array}{l}10 \\
15 \\
25\end{array}$ & $\begin{array}{l}0.24 \\
0.24 \\
0.24\end{array}$ & $\begin{array}{l}27.9 \pm 0.2 \\
32.3 \pm 1.4 \\
36.4 \pm 0.7\end{array}$ & Deacon et al. (1987) \\
\hline Speckled dace Rhinichthys osculus & $\begin{array}{l}10 \\
15 \\
25\end{array}$ & $\begin{array}{l}0.24 \\
0.24 \\
0.24\end{array}$ & $\begin{array}{l}30.5 \pm 1.6 \\
32.6 \pm 0.5 \\
36.8 \pm 0.6\end{array}$ & Deacon et al. (1987) \\
\hline Woundfin Plagopterus argentissimus & $\begin{array}{l}10 \\
15 \\
25\end{array}$ & $\begin{array}{l}0.24 \\
0.24 \\
0.24\end{array}$ & $\begin{array}{l}30.7 \pm 0.2 \\
33.6 \pm 1.0 \\
39.5 \pm 0.2\end{array}$ & Deacon et al. (1987) \\
\hline Sand shiner Notropis stramineus & $\begin{array}{l}21 \\
26\end{array}$ & $\begin{array}{l}0.3 \\
0.3\end{array}$ & $\begin{array}{l}33.0 \pm 2.0 \\
36.8 \pm 2.0\end{array}$ & Q. Dai et al. (unpubl. data) \\
\hline
\end{tabular}


neus, which were sampled at the same site and acclimated at the same temperatures as bigeye chub (Q. Dai et al. unpubl. data), had similar $\mathrm{CT}_{\max }$ values (Table 4). The $\mathrm{CT}_{\max }$ of bigeye chub with acclimation temperatures at 21 and $26^{\circ} \mathrm{C}$ were both around the median of $\mathrm{CT}_{\max }$ range distributions, compared to similar acclimation temperatures (i.e. $\pm 2^{\circ} \mathrm{C}$ ) for other species (Table 4). In streams, thermal tolerance could play an important role in determining competitive advantages when different species have highly overlapping niches. For example, Mojave tui chub Gila bicolor mohavensis, which are native to the Mohave River, California, were partly displaced by the introduced Arroyo chub Gila orcutti because of Arroyo chub's better tolerance of fluctuating temperature conditions, which provided them with a competitive advantage over Mojave tui chub (Castleberry \& Cech 1986). In the future, climate change will generate more frequent and extreme heat waves (Seneviratne et al. 2014, IPCC 2018). Therefore, it would be advantageous for future studies to conduct similar work using acclimation temperatures higher than those in the current experiment to better compare thermal tolerance of bigeye chub with other sympatric species, and to provide improved estimations for future habitat occupancy of streams and creeks.

The $U_{\text {crit }}$ of bigeye chub was over $10 \mathrm{BL} \mathrm{s}^{-1}$ for both acclimation temperatures, and the $5^{\circ} \mathrm{C}$ difference in acclimation temperature did not impair or improve swimming performance. $U_{\text {crit }}$ is commonly used to estimate maximum aerobic swimming ability (Brauner et al. 1994) and is assumed to represent maximum cardiac performance (Farrell \& Steffensen 1987). In this way, $U_{\text {crit }}$ has been used to quantify the effects of different factors, such as temperature, on swimming performance, and to predict the ecological effects of these factors on fishes (Plaut 2001). Compared to several other small Leuciscinae fishes (Table 5), bigeye chub are strong swimmers, with higher $U_{\text {crit }}\left(\mathrm{cm} \mathrm{s}^{-1}\right.$ and BL s${ }^{-1}$ ) (Boyd \& Parsons 1998, Kolok et al. 1998, Webb 1998, Tritico \& Cotel 2010, Nichols et al. 2018) despite different acclimation temperatures that could limit direct $U_{\text {crit }}$ comparisons across species. Additionally, although the $U_{\text {crit }}$ of bigeye chub is relatively high, it is possible that the swimming performance of the individuals generated in our swim tunnel is an underestimation of true swimming ability in the wild. For example, Boyd \& Parsons (1998) showed that the $U_{\text {crit }}$ of schooling fish was higher than individuals swimming alone, meaning that wild bigeye chub may exceed values shown here if they aggregate into shoals. Also, Castro-Santos (2011) argued that the small chambers of swim tunnels under controlled conditions in the laboratory prevented fish from exhibiting free-swimming behaviors, thus causing underestimation of swimming performance. As a species most often found in streams and creeks (Tiemann et al. 2004), good swimming performance is likely critical for bigeye chub to flourish under conditions of variable discharge rates that can occur in streams. Because the $5^{\circ} \mathrm{C}$ acclimation temperature increase from 21 to $26^{\circ} \mathrm{C}$ did not impair the swimming ability of bigeye chub, future studies with higher acclimation temperatures could better inform the threshold of its upper thermal limits for aerobic swimming performance. In addition, future work that combines $U_{\text {crit }}$ testing at different temperatures with metabolic rate data (oxy-

Table 5. Comparisons of the critical swimming speed $\left(U_{\text {crit }}\right)$ of bigeye chub with other small Leuciscinae fishes. BL: body length. Data are shown as mean \pm SD when possible

\begin{tabular}{|lccccc|}
\hline Species & $\begin{array}{c}\text { Acclimation } \\
\text { temperature }\left({ }^{\circ} \mathrm{C}\right)\end{array}$ & $\begin{array}{c}\mathrm{BL} \\
(\mathrm{mm})\end{array}$ & $\begin{array}{c}U_{\text {crit }} \\
\left(\mathrm{cm} \mathrm{s}^{-1}\right)\end{array}$ & $\begin{array}{c}U_{\text {crit }} \\
\left(\mathrm{BL} \mathrm{s}^{-1}\right)\end{array}$ & Source \\
\hline Bigeye chub Hybopsis amblops & 21 & $66.8 \pm 7.8$ & $71.1 \pm 3.7$ & $10.8 \pm 1.5$ & This study \\
Creek chub Semotilus atromaculatus & 26 & $67.4 \pm 5.7$ & $76.6 \pm 10.8$ & $11.3 \pm 0.9$ & Tritico \& Cotel (2010) \\
River chub Nocomis micropogon & 20.5 & $122 \pm 12$ & $53.2 \pm 2.4$ & $4.4^{\mathrm{a}}$ & Webb (1998) \\
& 13 & $105 \pm 31$ & $59 \pm 16$ & $5.6^{\mathrm{a}}$ & Boyd \& Parsons (1998) \\
Golden shiner Notemigonus crysoleucas & $21-23$ & $61 \pm 3.5$ & $25.6 \pm 5.5$ & $4.2^{\mathrm{a}}$ & Kolok et al. (1998) \\
Fathead minnow Pimephales promelas & 24 & $61 \pm 4$ & $44.7 \pm 4.1$ & $7.3^{\mathrm{a}}$ & Nichols et al. (2018) \\
Spotfin shiner Cyprinella spiloptera & 20 & $27-95$ & $60.8 \pm 11.3$ & & Nichols et al. (2018 \\
Bluntnose minnow Pimephales notatus & 20 & $49-83$ & $63.0 \pm 22.7$ & &
\end{tabular}


gen consumption data) will provide a comprehensive understanding of the responses of bigeye chub to future climatic stressors.

Bigeye chub did not show a difference in burst swimming durations with a $5^{\circ} \mathrm{C}$ difference in acclimation. For fish, anaerobic (burst) swimming is used for short-duration, high-intensity swimming to avoid predation, capture food, and overcome abrupt transitions through difficult flow conditions (Plaut 2001, Hasler et al. 2009). For example, Taylor \& McPhail (1985) found newly emerged coho salmon Oncorhynchus kisutch with better burst swimming performance were less susceptible to predation compared to conspecifics. For burst swimming duration of bigeye chub, although there was no statistically significant difference between the 21 and $26^{\circ} \mathrm{C}$ groups, it is notable that there was an approximate $27 \%$ increase in duration that burst swimming ability improved at the higher acclimation temperature. Considering the modest sample sizes (6 in each group) and relatively large inter-individual variation of duration within each temperature group, future trials at higher acclimation temperatures could be performed to better explore the threshold of upper thermal limits for burst swimming performance in this species. Regardless, our study shows that a $5^{\circ} \mathrm{C}$ increase in acclimation temperature from 21 to $26^{\circ} \mathrm{C}$ did not impair or improve the burst swimming duration of bigeye chub.

Comparing the results of behavioral tests with available environmental data will provide information that assists in the estimation of bigeye chub distribution. The Illinois Environmental Protection Agency maintained a stream temperature monitoring station at our sampling location in 2016. Records from this station showed mean water temperatures in June and August were $21.4^{\circ} \mathrm{C}$ and $26.7^{\circ} \mathrm{C}$, respectively, which approximate the acclimation temperatures used in this study (https://www2.illinois.gov/epa/topics/water-quality/ monitoring/Pages/river-and-stream.aspx). In both months, daily variation in temperature was approximately $5^{\circ} \mathrm{C}$, with maximum temperatures reaching $31.8^{\circ} \mathrm{C}$ in the afternoon in August. In addition, the United States Geological Survey maintains a separate stream monitoring station (Site 03339000; https://waterdata.usgs.gov/il/nwis/rt) $25 \mathrm{~km}$ downstream from our collection site. Data from this station indicate that mean water temperatures in August (the hottest month of the year) averaged $26.9^{\circ} \mathrm{C}$ from 2015 to 2018 , and average daily temperature once reached $29.1^{\circ} \mathrm{C}$ in August. Together, data from these 2 sites suggests that the daily maximum temperature at the site where fish were collected does not exceed either the $\mathrm{CT}_{\max }$ or $\mathrm{AT}_{\max }$ observed in this study.
These thermal data likely partially explain why we were able to sample a large number (40) of stateendangered bigeye chub at this site, which is near the middle of its geographical distribution (Page \& Burr 2011). Sunday et al. (2012) found that, under climate warming, ectotherms were predicted to shift their distribution ranges northward when considered globally. However, the greatest declines in bigeye chub populations appear to have occurred near the northern edge of their distribution (Tiemann et al. 2004). To better define whether temperature could be a factor influencing the range distribution of bigeye chub, we recommend that future studies consider not only elevated temperature, but also other forms of thermal stress such as heat waves. Meehl \& Tebaldi (2004), for example, predicted more frequent and longer lasting heat waves in the northern portion of the midwestern region of North America compared to the southern portion. Also, in addition to considering thermal conditions alone, there are a number of other stressors that should be considered as part of habitat evaluations, particularly in terms of synergistic interactions with temperature changes (Folt et al. 1999). For example, both elevated water temperatures and eutrophication can result in an unavoidable decline in dissolved oxygen (Wetzel 2001), and this reduction in oxygen levels could exacerbate the sensitivity of bigeye chub to a range of environmental stressors. Holmstrup et al. (2010) reviewed the synergistic effects of a number of stressors, including low oxygen, on a number of pollutants in aquatic ecosystems, while Wajsbrot et al. (1991) showed that juvenile gilthead seabream Sparus aurata were more sensitive to ammonia toxicity at low dissolved oxygen levels relative to fish in normoxia. Future work should therefore be conducted on bigeye chub collected from a greater range of latitudes, coupled with more information on environmental components (e.g. dissolved oxygen and nutrient levels) and a more specific regional climate projection, to better predict thermal refugia and habitat suitability for bigeye chub across their range (Sunday et al. 2014, Pinsky et al. 2019).

Our study with bigeye chub from the Vermillion River, IL, USA, quantified both its thermal limits and thermal impacts on swimming performance, and demonstrated that natural thermal variation at this site likely did not exceed the thermal capacity of bigeye chub in the summer. In the future, results from our laboratory work should be better verified in the field; for example, either by sampling habitats with known thermal properties or through biotelemetry (Schrank et al. 2003). Overall, results from this study can help 
incorporate temperature into predicting range distribution of bigeye chub under conditions of climate change and point source thermal pollution (e.g. power plant discharge), and guide the protection and restoration of bigeye chub and other endangered species.

Acknowledgements. This study was funded by the Illinois Department of Natural Resources (\#909-42212-1900-0000). We thank Trent Thomas, Mike Garthaus, Josh Sherwood, and John Bieber for assistance with field sampling; Justin Rondon, John Bieber, and Katey Strailey for help with the laboratory experiment; Nathan Grider, Trent Thomas, Brian Metzke, and Brian Koch for comments and temperature data; Bradley Hayes and Toniann Keiling for review. Comments from 2 anonymous reviewers improved the manuscript. This study was approved by the University of Illinois, Urbana-Champaign's Institutional Animal Care and Use Committee (IACUC) (\#18162), as well as the Endangered and Threatened Species Permit (\#3647) from the Illinois Department of Natural Resources.

\section{LITERATURE CITED}

Amundsen T, Forsgren E (2001) Male mate choice selects for female coloration in a fish. Proc Natl Acad Sci USA 98: 13155-13160

Angermeier PL (1995) Ecological attributes of extinctionprone species: loss of freshwater fishes of Virginia. Conserv Biol 9:143-158

Avise JC, Ayala FJ (1976) Genetic differentiation in speciose versus depauperate phylads: evidence from the California minnows. Evolution 30:46-58

Becker CD, Genoway RG (1979) Evaluation of the critical thermal maximum for determining thermal tolerance of freshwater fish. Environ Biol Fishes 4:245-256

Beitinger TL, Lutterschmidt WI (2011) Measures of thermal tolerance. In: Farrell AP (ed) Encyclopedia of fish physiology: from genome to environment. Academic Press, Cambridge, MA, p 1695-1702

Beitinger TL, Bennett WA, McCauley RW (2000) Temperature tolerances of North American freshwater fishes exposed to dynamic changes in temperature. Environ Biol Fishes 58:237-275

Bell WH, Terhune LDB (1970) Water tunnel design for fisheries research. Fish Res Board Can Tech Rep 195:1-69

Bennett WA, Beitinger TL (1997) Temperature tolerance of the sheepshead minnow, Cyprinodon variegatus. Copeia 1997:77-87

Berendzen PB, Gamble T, Simons AM (2008) Phylogeography of the bigeye chub Hybopsis amblops (Teleostei: Cypriniformes): early Pleistocene diversification and post-glacial range expansion. J Fish Biol 73:2021-2039

Bonar SA, Carveth CJ, Widmer AM, Simms J (2005) Upper temperature tolerance of loach minnow and spikedace under acute, chronic, and fluctuating thermal regimes. Fisheries Research Report No. 04-05. Arizona Cooperative Fish and Wildlife Research Unit, US Geological Survey, Tucson, AZ

Boschung HT, Mayden RL (2004) Fishes of Alabama. Smithsonian Books, Washington, DC

Boyd GL, Parsons GR (1998) Swimming performance and behavior of golden shiner, Notemigonus crysoleucas, while schooling. Copeia 1998:467-471

* Brauner CJ, Iwama GK, Randall DJ (1994) The effect of short-duration seawater exposure on the swimming performance of wild and hatchery-reared juvenile coho salmon (Oncorhynchus kisutch) during smoltification. Can J Fish Aquat Sci 51:2188-2194

*Bett JR (1964) The respiratory metabolism and swimming performance of young sockeye salmon. J Fish Res Board Can 21:1183-1226

Carveth CJ, Widmer AM, Bonar SA (2006) Comparison of upper thermal tolerances of native and nonnative fish species in Arizona. Trans Am Fish Soc 135:1433-1440

* Castleberry DT, Cech JJ (1986) Physiological responses of a native and an introduced desert fish to environmental stressors. Ecology 67:912-918

Castro-Santos T (2011) Applied aspects of fish swimming performance. In: Farrell AP (ed) Encyclopedia of fish physiology: from genome to environment. Academic Press, Cambridge, MA, p 1652-1663

Crawley MJ (2013) The R book, $2^{\text {nd }}$ edn. Wiley, Hoboken, NJ

* Currie RJ, Bennett WA, Beitinger TL (1998) Critical thermal minima and maxima of three freshwater game-fish species acclimated to constant temperatures. Environ Biol Fishes 51:187-200

Deacon JE, Schumann PB, Stuenkel EL (1987) Thermal tolerances and preferences of fishes of the Virgin River system (Utah, Arizona, Nevada). Great Basin Nat 47: 538-546

Farrell AP, Steffensen JF (1987) An analysis of the energetic cost of the branchial and cardiac pumps during sustained swimming in trout. Fish Physiol Biochem 4:73-79

Folt CL, Chen CY, Moore MV, Burnaford J (1999) Synergism and antagonism among multiple stressors. Limnol Oceanogr 44:864-877

*Hasler CT, Suski CD, Hanson KC, Cooke SJ, Philipp DP, Tufts BL (2009) Effect of water temperature on laboratory swimming performance and natural activity levels of adult largemouth bass. Can J Zool 87:589-596

*Hasnain SS, Shuter BJ, Minns CK (2013) Phylogeny influences the relationships linking key ecological thermal metrics for North American freshwater fish species. Can J Fish Aquat Sci 70:964-972

* Heath S, Bennett WA, Kennedy J, Beitinger TL (1994) Heat and cold tolerance of the fathead minnow, Pimephales promelas, exposed to the synthetic pyrethroid cyfluthrin. Can J Fish Aquat Sci 51:437-440

* Holmstrup M, Bindesbøl AM, Oostingh GJ, Duschl A and others (2010) Interactions between effects of environmental chemicals and natural stressors: a review. Sci Total Environ 408:3746-3762

Huey RB (1991) Physiological consequences of habitat selection. Am Nat 137:S91-S115

Illinois Endangered Species Protection Board (2015) Checklist of endangered and threatened animals and plants of Illinois. Illinois Endangered Species Protection Board, Springfield, IL

IPCC (2018) Summary for policymakers. In: Masson-Delmotte V, Zhai P, Pörtner HO, Roberts D and others (eds) Global warming of $1.5^{\circ} \mathrm{C}$. An IPCC special report on the impacts of global warming of $1.5^{\circ} \mathrm{C}$ above pre-industrial levels and related global greenhouse gas emission pathways, in the context of strengthening the global response to the threat of climate change, sustainable development, and efforts to eradicate poverty. WHO, Geneva, p 1-32 
Kern P, Cramp RL, Gordos MA, Watson JR, Franklin CE (2018) Measuring $U_{\text {crit }}$ and endurance: equipment choice influences estimates of fish swimming performance. J Fish Biol 92:237-247

Killen SS, Atkinson D, Glazier DS (2010) The intraspecific scaling of metabolic rate with body mass in fishes depends on lifestyle and temperature. Ecol Lett 13:184-193

King TL, Zimmerman EG, Beitinger TL (1985) Concordant variation in thermal tolerance and allozymes of the red shiner, Notropis lutrensis, inhabiting tailwater sections of the Brazos River, Texas. Environ Biol Fishes 13:49-57

Kolok AS, Plaisance EP, Abdelghani A (1998) Individual variation in the swimming performance of fishes: an overlooked source of variation in toxicity studies. Environ Toxicol Chem 17:282-285

Lee CG, Farrell AP, Lotto A, MacNutt MJ, Hinch SG, Healey MC (2003) The effect of temperature on swimming performance and oxygen consumption in adult sockeye (Oncorhynchus nerka) and coho (O. kisutch) salmon stocks. J Exp Biol 206:3239-3251

Lutterschmidt WI, Hutchison VH (1997) The critical thermal maximum: data to support the onset of spasms as the definitive end point. Can J Zool 75:1553-1560

Magnuson JJ, Crowder LB, Medvick PA (1979) Temperature as an ecological resource. Am Zool 19:331-343

McClanahan LL, Feldmeth CR, Jones J, Soltz DL (1986) Energetics, salinity and temperature tolerance in the Mohave tui chub, Gila bicolor mohavensis. Copeia 1986: 45-52

Meehl GA, Tebaldi C (2004) More intense, more frequent, and longer lasting heat waves in the 21st century. Science 305:994-997

Morgan R, Finnøen MH, Jutfelt F (2018) $\mathrm{CT}_{\max }$ is repeatable and doesn't reduce growth in zebrafish. Sci Rep 8:7099

* Naiman RJ, Décamps H (1997) The ecology of interfaces: riparian zones. Annu Rev Ecol Syst 28:621-658

Neumann RM, Guy CS, Willis DW (2012) Length, weight, and associated indices. In: Zale AV, Parrish DL, Sutton TM (eds) Fisheries techniques, $3^{\text {rd }}$ edn. American Fisheries Society, Bethesda, MD, p 637-676

Nichols C, Smith A, Huelsman S, Schemmel C, Doll JC, Jacquemin SJ (2018) Preliminary understanding of complexities in swimming performance of common minnow (Cyprinidae) taxa. Ohio J Sci 118:16-24

Page LM, Burr BM (2011) A field guide to freshwater fishes of North America north of Mexico, $2^{\text {nd }}$ edn. Houghton Mifflin Harcourt, Boston, MA

Page LM, Retzer ME (2002) The status of Illinois' rarest fishes and crustaceans. Trans Ill State Acad Sci 95:311-326

Pfleiger WL (1997) The fishes of Missouri, revised edn. Missouri Department of Conservation, Jefferson City, MO

* Pinsky ML, Eikeset AM, McCauley DJ, Payne JL, Sunday JM (2019) Greater vulnerability to warming of marine versus terrestrial ectotherms. Nature 569:108-111

* Plaut I (2001) Critical swimming speed: its ecological relevance. Comp Biochem Physiol A Mol Integr Physiol 131: 41-50

R Core Team (2019) R: a language and environment for statistical computing. R Foundation for Statistical Computing, Vienna

Richards VL, Beitinger TL (1995) Reciprocal influences of temperature and copper on survival of fathead minnows,
Pimephales promelas. Bull Environ Contam Toxicol 55: 230-236

* Rutledge CJ, Beitinger TL (1989) The effects of dissolved oxygen and aquatic surface respiration on the critical thermal maxima of three intermittent-stream fishes. Environ Biol Fishes 24:137-143

* Schrank AJ, Rahel FJ, Johnstone HC (2003) Evaluating laboratory-derived thermal criteria in the field: an example involving Bonneville cutthroat trout. Trans Am Fish Soc 132:100-109

* Sears MW, Raskin E, Angilletta MJ (2011) The world is not flat: defining relevant thermal landscapes in the context of climate change. Integr Comp Biol 51:666-675

* Seneviratne SI, Donat MG, Mueller B, Alexander LV (2014) No pause in the increase of hot temperature extremes. Nat Clim Chang 4:161-163

* Sunday JM, Bates AE, Dulvy NK (2012) Thermal tolerance and the global redistribution of animals. Nat Clim Chang 2:686-690

* Sunday JM, Bates AE, Kearney MR, Colwell RK, Dulvy NK, Longino JT, Huey RB (2014) Thermal-safety margins and the necessity of thermoregulatory behavior across latitude and elevation. Proc Natl Acad Sci USA 111:5610-5615

Taylor EB, McPhail JD (1985) Burst swimming and sizerelated predation of newly emerged coho salmon Oncorhynchus kisutch. Trans Am Fish Soc 114:546-551

* Terblanche JS, Hoffmann AA, Mitchell KA, Rako L, le Roux PC, Chown SL (2011) Ecologically relevant measures of tolerance to potentially lethal temperatures. J Exp Biol 214:3713-3725

Tiemann JS, Retzer ME, Tiemann BL (2004) Range expansion of the state-endangered bigeye chub Hybopsis amblops (Rafinesque) in Illinois. Trans Ill State Acad Sci 97:255-257

* Tritico HM, Cotel AJ (2010) The effects of turbulent eddies on the stability and critical swimming speed of creek chub (Semotilus atromaculatus). J Exp Biol 213:2284-2293

U Underwood ZE, Myrick CA, Rogers KB (2012) Effect of acclimation temperature on the upper thermal tolerance of Colorado River cutthroat trout Oncorhynchus clarkii pleuriticus: thermal limits of a North American salmonid. J Fish Biol 80:2420-2433

* Underwood ZE, Myrick CA, Compton RI (2014) Comparative swimming performance of five Catostomus species and roundtail chub. N Am J Fish Manag 34:753-763

*Wajsbrot N, Gasith A, Krom MD, Popper DM (1991) Acute toxicity of ammonia to juvenile gilthead seabream Sparus aurata under reduced oxygen levels. Aquaculture 92: $277-288$

Warren ML, Burr BM (1988) Reassessment of the Illinois ranges of the bigeye chub, Hybopsis amblops, and the pallid shiner, Notropis amnis. Ohio J Sci 88:181-183

* Webb PW (1998) Entrainment by river chub Nocomis micropogon and smallmouth bass Micropterus dolomieu on cylinders. J Exp Biol 201:2403-2412

Wetzel RG (2001) Limnology, $3^{\text {rd }}$ edn. Academic Press, San Diego, CA

Xia J, Ma Y, Fu C, Fu S, Cooke SJ (2017) Effects of temperature acclimation on the critical thermal limits and swimming performance of Brachymystax lenok tsinlingensis: a threatened fish in Qinling Mountain region of China. Ecol Res 32:61-70 


\section{Appendix}

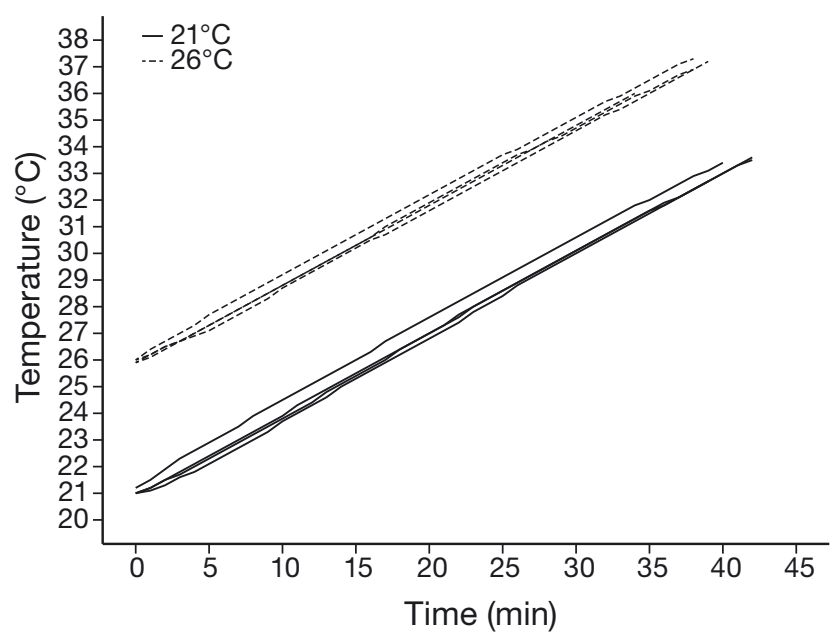

Fig. A1. Change in water temperature over time during thermal tests for bigeye chub acclimated to $21^{\circ} \mathrm{C}$ (solid lines) and $26^{\circ} \mathrm{C}$ (dashed lines). Water temperature was recorded every 1 min from the test tank using a handheld meter; 4 trials were run at each acclimation temperature. Equations for mean temperature increase: Temperature $=0.31 \times$ Time $+21.0, \mathrm{R}^{2}=$ 0.995 (for $21^{\circ} \mathrm{C}$ groups); Temperature $=0.30 \times$ Time +25.9 , $\mathrm{R}^{2}=0.996$ (for $26^{\circ} \mathrm{C}$ groups)
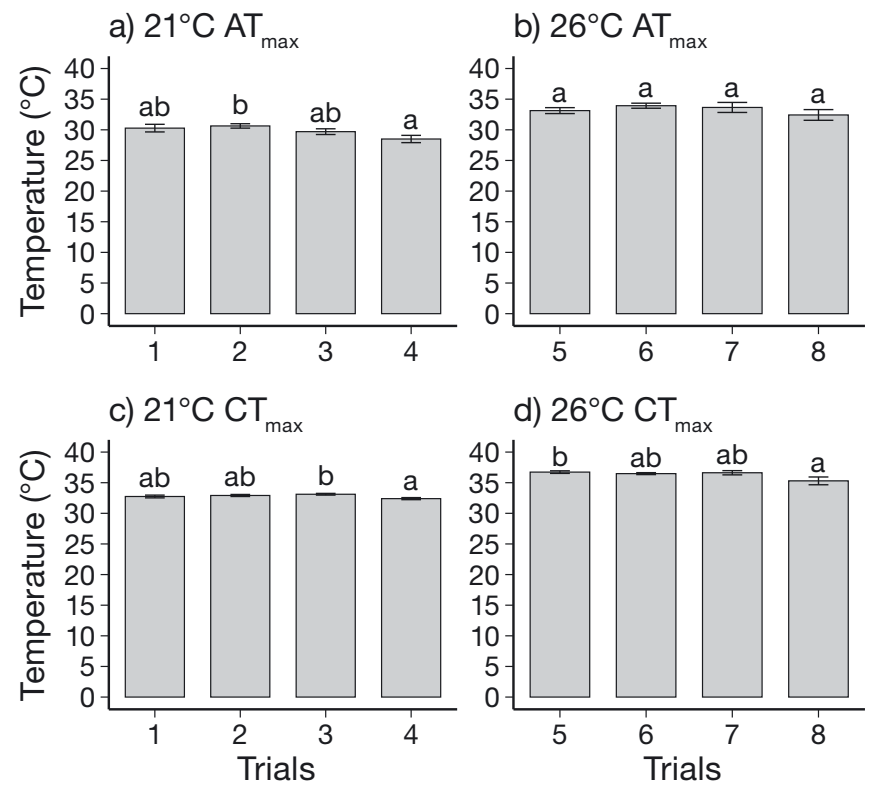

d) $26^{\circ} \mathrm{C} \mathrm{CT}$

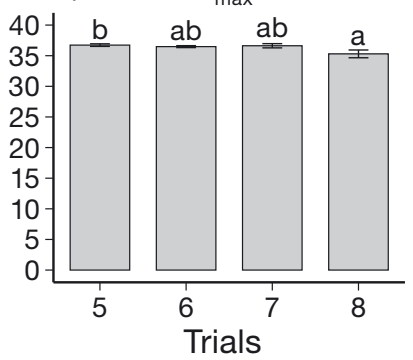

Fig. A2. Temperature at which bigeye chub acclimated to either 21 or $26^{\circ} \mathrm{C}$ showed either $(\mathrm{a}, \mathrm{b})$ avoidance behaviors (upper incipient avoidance temperature, $\mathrm{AT}_{\max }$ ) or $(\mathrm{c}, \mathrm{d})$ lost equilibrium (critical thermal maximum, $\mathrm{CT}_{\max }$ ). For each temperature/response combination, data were generated across 4 replicate trials (groups); each bar corresponds to 1 trial. Sample sizes for each trial were $n=4$ or 6 . Statistical differences across trials are denoted by dissimilar letters above bars (Tukey's post hoc test, $\mathrm{p}<0.05$ )

Table A1. Results of a 2-way ANOVA comparing the effect of acclimation (either 21 or $26^{\circ} \mathrm{C}$ ), behavioral response (either avoidance behaviors [upper incipient avoidance temperature, $\mathrm{AT}_{\max }$ ] or lost equilibrium [critical thermal maximum, $\left.\mathrm{CT}_{\max }\right]$ ), and the interaction of acclimation and behavioral response on the temperature at which bigeye chub displayed behavioral changes. Data are shown in Table 2; significant factors are shown in bold

\begin{tabular}{|lcrrr|}
\hline & df & $\begin{array}{c}\text { Sum of } \\
\text { squares }\end{array}$ & $F$ & p-value \\
\hline Response & $\mathbf{1}$ & $\mathbf{1 8 0 . 0 0}$ & $\mathbf{1 6 2 . 4 4 5}$ & $<\mathbf{0 . 0 0 1}$ \\
Acclimation & $\mathbf{1}$ & $\mathbf{2 4 4 . 3 0}$ & $\mathbf{2 2 0 . 4 7 5}$ & $<\mathbf{0 . 0 0 1}$ \\
Response $\times$ acclimation & 1 & 0.00 & 0.004 & 0.949 \\
Residuals & 76 & 84.21 & & \\
\hline
\end{tabular}

Editorial responsibility: J. Rudi Strickler, Milwaukee, Wisconsin, USA
Submitted: April 23, 2019; Accepted: August 9, 2019 Proofs received from author(s): September 27, 2019 